\title{
BULLYING BEHAVIOUR OF ADOLESCENTS BASED ON GENDER, GANG AND FAMILY
}

\author{
Kadek Ayu Erika, Dian Atma Pertiwi, Tuti Seniwati \\ School of Nursing, Hasanuddin University, Makassar, Indonesia \\ Email:kadek20_uh@yahoo.com
}

\begin{abstract}
Introduction: Bullying is a social problem which is characterised by aggressive violent behaviour done continuously and has an adverse impact on victims and its subject and happens at school. This study aims to find out the description of knowledge and adolescents' behaviour with regard to bullying based on their age, gang and family. Methods: This study used an analytic descriptive design with some samples - 246 adolescents from grade 1, 2, and 3 of senior high school which used stratified random sampling. Instruments of this study were a knowledge questioner and a modified version of The Bullying Prevalence Questionnaire in Guttman and Likert scale. Data analysis used cross tabulation. Result: Data show that adolescents have a good knowledge (93.9\%) of bullying and less $(6.1 \%)$. Bullying subjects were $93.9 \%$ and victims $94.7 \%$. Forms of verbal bullying indicated the subjects $(93.1 \%)$ and victims $(92.3 \%)$. The majority of bullying subjects were males $(94.1 \%)$, and the majority of victims were women (96.3\%). Numbers of bullying subjects do not have a gang $(94.5 \%)$, while those with a gang as victims $(95.2 \%)$. There were five adolescents who live in stepfamilies who became subjects and victims of bullying. Conclusion: The majority of adolescents have good knowledge about bullying, the vast majority of cases of bullying were verbal bullying with subjects and victims of bullying occurring in all classes. The majority of bullying subjects do not have a gang, and the majority of victims have a gang. Almost all adolescents with different family types become subjects and victims of bullying. Therefore, an intensive educational and spiritual effort needs to be made to change the behaviour of adolescents so that they are adolescents with good character.
\end{abstract}

Keywords: Bullying, gender, gang, family.

\section{INTRODUCTION}

Bullying behaviour is a social problem that is part of the violent behaviour done aggressively with discrete hurt either physically, verbally, psychologically, through an intermediary and without an intermediary, violating the rights, the power difference between perpetrator and victim and which is repeatedly performed (Lai, Ye, \& Chang, 2008). In recent years, the phenomenon of bullying has become a source of concern all over the world and it is constantly increasing and significantly mainly occurring in children and adolescents, especially at school age (Lai et al., 2008).

The World Health Organization (2012) reported that the health behaviour of schoolage children in Europe ranges from 2\% to $27 \%$ of girls becoming victims of bullying, and $5 \%$ to $32 \%$ of boys. According to statistics on bullying, the data also demonstrates that $70.6 \%$ of students in the United States (US) have watched bullying in their schools and more than $30 \%$ of students reported experiencing bullying (Bullying Statistic, 2015). Moreover, according to data from the National Center for Education (NCE) (2007), approximately 3.2 million youth aged 12-18 have reported experiencing some form of bullying, and more than 160,000 children missed school every day because of trauma as a result of the terror received in school (Santoyosep, 2013). According to Cokokinarto et al. (2013), cases of bullying that occur in Indonesia, including in the order of 2 ads highest in the world after Japan, followed by Canada and the US. This is also supported by the number of reports from the public to the Indonesian Child Protection Commission (KPAI) against bullying cases from 2011 to August 2014; there were 369 complaints which are about $25 \%$ of the total complaints in the field of education which has as many as 1480 cases (Setyawan, 2014).

The results of the study of the National Consortium Characters in the School Development Firmansyah (2014), showed that almost all schools in Indonesia experienced bullying. Based on this, the study stated that Indonesia was categorised as an emergency for bullying in schools. According to Edwards (2006) in Usman (2013), bullying is most common in high school because adolescence has a high level of egocentrism. Based on a survey conducted on 40 students of class XII in one secondary school (high school) in the city of Semarang, $32.5 \%$ of students had been a subject, victim, or witness of bullying; $27.5 \%$ had been a witness only, $10 \%$ were victims and 
witnesses; $7.5 \%$ were subjects or witnesses; and $25 \%$ were the subject of bullying alone (Sugiariyanti, 2009).

According to Soedjatmiko, Nurhamzah, Maureen, \& Wiguna) (2013), most victims of bullying will experience a negative impact in the form of barriers to actualising themselves, mental disorders and psychosocial disorders. This is because students feel they are in a state of distress, danger or insecurity and comfortable, have a sense of worthlessness, difficulty concentrating, find it difficult to socialise within their environment, have poor self-esteem, depression which affects academic performance and can even lead to suicide (Sejiwa, 2008). One of the effects of bullying is a decrease in the level of achievement in school. This is evidenced by the results of research by Dwipayanti \& Indrawati (2014), that the higher the bullying experienced by victims of bullying, the lower the academic achievement.

Research on students 'knowledge about bullying', especially in the area of Makassar South Sulawesi has not been done, while the students' knowledge is very influential in bullying behavior before further action. Some studies say that to solve a case of bullying, the intervention must be carried out with the perpetrators and the victims. Effectiveness depends on the participants' knowledge, empathy, and adherence to the intervention (Chatters, 2012). Based on interviews with three students of SMA Negeri 1 Tanete Rilau, it was found that violence is very common, especially during student orientation periods (MOS) occurring between seniors and juniors. Also, the Coordinator of Counseling (BK) said that violence has occurred from year to year and the data recorded that several students had been threatened with expulsion from school. This study aims to describe the knowledge and behaviour of adolescents' bullying based on gender, gang and family.

\section{METHODS}

The study design is descriptive analysis with cross tabulation between the variables gender, having a gang and type of family with adolescent bullying behaviour. Research was conducted at SMAN 1 Tanete Rilau, District Tanete Rilau, Barru, South Sulawesi in October-November 2015. The population in this study were all adolescents in the $1^{\text {st }}, 2^{\text {nd }}$, and $3^{\text {rd }}$ grade of senior high school (SMA
Negeri 1 Tanete Rilau). In the 2015-2016 school year, there were 638 adolescents, with a sample of 246 adolescents selected by using a stratified random sampling technique. The samples for each class were obtained by selecting students who have an odd number on their student identification in each class. The inclusion criteria were teens at a research site for the study with a signed informed consent sheet.

The variable in this study concerning the knowledge of adolescents about bullying included definitions, characteristics, causes, impacts and forms of bullying consisting of verbal bullying, physical, psychosocial/mental, and cyberbullying; variable bullying behaviour can be identified as subjects and victims of bullying, obtained from respondents through a modified version of The Bullying Prevalence Questionnaire (physical, verbal, psychological/ mental and cyber), gender variable, gang variable, and family variable in terms of the biological family (living with parents and siblings), stepfamilies and non-biological families.

The instrument used in this study was to test the validity and reliability of knowledge about bullying including a questionnaire with the value of Cronbach's Alpha equalling 0.959 and a Corrected item-Total Correlation $>\mathrm{r}$ table (0.361), with 12 questions using the Guttman scale; The Bullying Prevalence Questionnaire was modified by researchers with the value of Cronbach's Alpha equalling 0.921 and Corrected item-Total Correlation> $r$ table (0.361), with 32 questions containing subjects and, for victims of bullying, using a Likert scale; and biodata respondents.

The data were processed and analysed descriptively and presented in a frequency distribution table. Furthermore, bullying behavior was analysed in cross tabulation with the variables gender, gang and family type.

\section{RESULTS}

The frequency distribution based on the characteristics of the respondent can be seen in Table 1, based on the knowledge and behaviour of bullying in Table 2, and forms of bullying in Table 3 . Table 1 shows that most respondents were female adolescents $(65.4 \%)$, in grade 3 , totalling 87 (35.4\%), and only 63 respondents 
Table 1. Frequency Distribution of Respondents by Gender, Class, Gang and Family type $(n=246)$

\begin{tabular}{|c|c|c|}
\hline Characteristics of Respondents & $\mathrm{n}$ & $\%$ \\
\hline \multicolumn{3}{|l|}{ Gender } \\
\hline Male & 85 & 34,6 \\
\hline Female & 161 & 65,4 \\
\hline \multicolumn{3}{|l|}{ Grade } \\
\hline I & 81 & 32,9 \\
\hline II & 78 & 31,7 \\
\hline III & 87 & 35,4 \\
\hline \multicolumn{3}{|l|}{ Having Gang } \\
\hline Yes & 63 & 25,6 \\
\hline No & 183 & 74,4 \\
\hline \multicolumn{3}{|l|}{ Family Type } \\
\hline Biological Family & 203 & 82,5 \\
\hline Step Family & 5 & 2 \\
\hline Non-Biological Family & 38 & 15,4 \\
\hline
\end{tabular}

Table 2. Frequency Distribution of Respondents by Knowledge and Bullying Behaviour $(n=246)$

\begin{tabular}{lccc} 
& Knowledge & $\mathrm{n}$ & $\mathbf{\%}$ \\
\hline Good & & 231 & 93,9 \\
Not Good & 15 & 6,1 \\
\hline & Behaviour & & \\
\hline Doing Bullying & & 231 & 93,9 \\
Not Doing Bullying & 15 & 6,1 \\
\hline Victims of Bullying & 233 & 94,7 \\
Not Victims of Bullying & 13 & 5,3 \\
\hline
\end{tabular}

Table 3 Frequency Distribution of Respondents by Forms of Bullying

\begin{tabular}{lcc}
\hline & Subjects & Victims \\
\cline { 2 - 3 } Form of Bullying & $\%$ & $\%$ \\
\hline Subjects of Physical & 74 & 83,7 \\
Non-Subjects of Physical & 26 & 16,3 \\
Subjects of Verbal & 93,1 & 92,3 \\
Non-Subjects of Verbal & 6,9 & 7,7 \\
Subjects of Psychosocial/ Mental & 73,6 & 67,4 \\
Non-Subjects of Psychosocial & 26,4 & 32,6 \\
Subjects of Cyber Bullying & 24,7 & 28,3 \\
Non- Subjects of Cyber Bullying & 75,3 & 71,7 \\
\hline
\end{tabular}

had a gang. The majority of respondents lived with a biological family, namely 203 adolescents $(82.5 \%)$.

Table 2 shows that the majority of the 246 respondents had a good knowledge of bullying - 231 adolescents (93.9\%). While the number of bullying subjects was 231 adolescents $(93.9 \%)$ and 233 adolescents $(94.7 \%)$ as victims of bullying. Table 3 shows that of the 231 bullying subjects, as many as $74 \%$ (171 adolescents) did the physical bullying, 93.1\% (215 adolescents) did the verbal bullying, $73.6 \%$ (170 adolescents) did the bullying psychosocially/ mentally, and 24, 7\% (57 adolescents) did cyber bullying. From the 231 respondents who became bullying subjects, there were some adolescents who became actors in more than one form of bullying. Of the 233 victims of bullying, as many as $83.7 \%$ (195 adolescents) were victims of physical bullying, 92.3\% (215 adolescents) were victims of verbal bullying, $67.4 \%$ (157 adolescents) were victims of bullying psychosocially/mentally, and $28.3 \%$ (66 respondents) became victims of cyber bullying.

Cross tabulation results of subjects and victims of bullying based on gender are shown in Table 4, having a gang in Table 5, and the type of family in Table 6 . Table 4 shows that 
Jurnal Ners Vol. 12 No. 1 April 2017: 126-132

Table 4. Frequency distribution of subjects and victims of bullying by sex $(n=246)$

\begin{tabular}{lcccc}
\hline \multirow{2}{*}{ Sex } & Subjects & Non Subjects & Victims & Non Victims \\
\cline { 2 - 5 } & $\%$ & $\%$ & $\%$ & $\%$ \\
\hline Male & 94,1 & 5,9 & 91,8 & 8,2 \\
Female & 93,8 & 6,2 & 96,3 & 3,7 \\
\hline
\end{tabular}

Table 5.Frequency distribution of subjects and victims of bullying according to gang group $(n=246)$

\begin{tabular}{lcccc}
\hline \multirow{2}{*}{ Gang Group } & Subjects & Not Subjects & Victims & Non-Victims \\
\cline { 2 - 5 } \multicolumn{1}{c}{$\%$} & $\%$ & $\%$ & $\%$ & $\%$ \\
\hline Having Gang & 92,1 & 7,9 & 95,2 & 4,8 \\
Non-Having Gang & 94,5 & 5,5 & 94,5 & 5,5 \\
\hline
\end{tabular}

Table 6. Frequency distribution of subjects and victims of bullying by family type $(n=246)$

\begin{tabular}{lcccc}
\hline \multirow{2}{*}{ Family Type } & Subjects & Not Subjects & Victims & Non-Victims \\
\cline { 2 - 5 } & $\%$ & $\%$ & $\%$ & $\%$ \\
\hline Biological Family & 92,6 & 7,4 & 94,1 & 5,9 \\
\hline Step family & 100 & 0 & 100 & 0 \\
\hline Non-Biological Family & 100 & 0 & 97,4 & 2,6 \\
\hline
\end{tabular}

the distribution of bullying behaviour by gender of 85 male adolescents showed 80 bullying subjects $(94.1 \%)$ and victims amounting to 78 adolescents $(91.8 \%)$. While the teenage girls' category of bullying subjects showed $151(93.8 \%)$ and the category for victims included $155(96.3 \%)$ of 161 girls.

Table 5 shows the distribution of bullying behaviour by gangs amongst 63 adolescents who have a gang, with categories of bullying subjects numbering $58(92.1 \%)$ and the victims numbering 60 adolescents (95.2\%). Amongst the 183 adolescents who did not have a gang, numbers of bullying subjects as well as victims were respectively 173 adolescents. (94.5\%).

Table 6 shows that the distribution of bullying behaviour by family of 203 adolescents who live with their biological families, included 188 bullying subjects (92.6\%) and 191 victims (94.1\%). There were five adolescents who lived with stepfamilies, showing that all adolescents $(100 \%)$ became bullying subjects or victims of bullying, while 38 adolescents lived with no biological family, and all of these adolescents (100\%) became bullying subjects and 37 adolescents were victims (97.4\%).

\section{DISCUSSION}

Data shows most adolescents have good knowledge about bullying. This is in line with research by Fajrin (2013) which shows a high percentage in terms of student knowledge about bullying at SMK PGRI Semarang. Knowledge of bullying is very closely related to the information that has been obtained by respondents from various sources. One source of information that is important for this knowledge is the mass media. Also, information can be derived from a teacher through the learning process. Based on Notoatmodjo (2010), people who have more resources will have a broad knowledge. Adolescent knowledge is based on indicators of knowledge about the definition of bullying, the characteristics of bullying, forms of bullying, bullying causes and effects of bullying. The results of the evaluation questionnaire on each question showed that more than half of the respondents answered wrongly the question about the forms of bullying. This could have been caused by information obtained by adolescents that bullying is confined in general to a form of violence. However, adolescents' information about forms of bullying is still lacking.

Bullying is a problem that occurs among children and adolescents and continues to receive attention from researchers. Based on the results of the categorisation of subject scores of subjects and victims of bullying it is known that as many as eight adolescents very often become bullying subjects, often (14 adolescents) and sometimes become subjects (80 adolescents). While very often the victim 
of bullying as much as 7 adolescents, often (20 adolescents) and 81 adolescents sometimes become victims of bullying. Thus, it shows that adolescents sometimes become subjects and victims of bullying. This is according to research conducted by Usman (2013) which indicates that the student encounters moderate bullying behaviour. But keep in mind also the subjects and victims of bullying in the category very often will have an impact on their adolescent psychology. This is supported by research KPAI (2013) which recorded 181 cases of bullying that led to a death. One of them is the case of a child aged 13 years in Bekasi who committed suicide in 2005 triggered by a sense of inferiority and frustration because he was often derided as a son of a chicken porridge seller by his school friends (Sari, 2015).

Results of identification about forms of bullying found that the highest form of bullying is verbal bullying. This was according to research conducted by Olweus (1994) and Kshirsagar (2007) in Nurhamzah et al. (2013) which said that the form of bullying which most often occurs in schools is verbal bullying. The results of our analysis showed that of 96.5\% (223 adolescents who became subjects as well as victims of bullying among other things as much as $87.1 \%$ experienced the physical form (149 adolescents), verbal $91.6 \%$ (197 adolescents), psychosocial/mental 70,6\% (120 adolescents) and cyber bullying 64.9\% (37 adolescents). This incident caused by a history of being bullied and to respond with violence also against his friend. In accordance with the theory of Harris \& Petrie (2003) the subjects of bullying who also became victims of bullying were adolescents who were bullied, and later also found ways to do the bullying to others as an expression of pleasure, revenge or a wish to be praised.

Bullies in adolescent males made up a higher percentage than girls. This is in line with the results of research by Aluede \& Oyaziwo (2006) and research by Magfirah \& Rachmawati (2009) which showed that adolescents were more often subjects as well as victims of bullying. The reason why adolescent males tend to be more aggressive psychologically is related to their need to show physical strength and adolescent males are also often exposed to games that have violent elements (Cerni Obrdalj \& Rumboldt, 2008). As the victims of bullying, adolescent girls make up a higher percentage than adolescent males. This is consistent with the theory of the Green et al. (2010) and research by Nurhamzah et al. (2013) which said that women were more likely to be bullied than men.

In a gang takes compactness starting of attraction which encouraged him to continue to be a member of the group and met intense and behave in line with the group members are commonly referred to conformity (Leviani, 2008). Research conducted by Nation et al. (2008) amongst 4386 middle school students and high school students from 151 middle and 92 high schools in Italy and the USA found an association between bullying behaviour and peer pressure to be accepted into a group. This study shows different results, with adolescents who do not have a gang making up a higher percentage of bullying subjects, while adolescents with a gang have a higher percentage as the victims of bullying. It can be influenced by several factors, among others, personal factors such as personality, attitudes, genetic predisposition and situational factors in the form of provocation, frustration, and drugs according to Anderson and Bushman (2002) in Usman (2008). In addition, a study reveals that high school students are no longer dependent on the pressures or decisions of their peers to do bullying behaviour, because, at such a time, high school students are able to think objectively about what to do and have increasing values of morality themselves (Eisenberg \& Aalsma, 2005).

Several studies have shown that families, especially parents, play an important role in children who commit acts of bullying. Rigby (2005) in a study of middle school students (200 students) and high school students (200 students) in Adelaide in South Australia revealed that bullying behaviour is caused by a lack of support from parents to children to do so and also found that students who did the bullying behaviour come from families with broken homes. The results showed that the respondents who were living with stepfamilies and not biological families all became bullying subjects, even though biological families also showed a high percentage. For the victims of bullying, all the adolescents who lived with stepfamilies became victims of bullying. According to Wiyani (2012), bullying subjects are usually the children of authoritarian parents, with 
violent behaviour, or those who are too permissive towards the aggressive behaviour of children. Thus, this study showed that although the respondents live with their biological parents, if they have parents who are authoritarian and often do violent behaviour this will form a distinct personality with respondents who lived with stepfamilies or not the biological parents who are educated without showing violence, so bullying behaviour does not occur. Apart from the family, the cause of bullying could come from the environment, especially the school environment. The school environment can be seen as a community ecosystem that connects between context and individual identity in a balanced manner so that a small change both in attitudes and behaviour at school can affect the behaviour of adolescents.

\section{CONCLUSION}

The majority of adolescents have good knowledge about bullying, but most adolescents do not know the forms of bullying. Forms of bullying in adolescents are mostly verbal bullying with subjects and victims of bullying occurring in all classes. The majority of bullying subjects do not have a gang, and the majority of victims have a group. Almost all adolescents with different family types become adolescents and victims of bullying.

The importance of an intensive educational and spiritual effort should be recognised to change the behaviour of adolescents to help them become adolescents with good character and conduct regular monitoring of the students and impose sanctions so that their awareness is raised to always behave well towards their peers.

\section{REFERENCE}

Aluede \& Oyaziwo. (2006). Teachers' opinions of school counseling programs in Nigerian secondary schools, 33, 42.

Bullying Statistic. (2015). Bullying Statistics, The Ultimate Guide ! |NoBullying|.

Cerni Obrdalj \& Rumboldt, M. (2008). Bullying among school children in postwar bosnia and herzegovina: crosssectional study. Croatian Medical Journal, 49(4), 528-535.

Chatters, S. J. (2012). Impact of Bullying Prevention Training on the Knowledge, Attitude, and Behavior of Pre-Education
Majors (Future Trainers). ProQuest

$L L C$. University of South Florida.

Cokokinarto, K., Suwasono, A. A., Salamoon, D. K., Petra, U. K. \& Cokokinarto, K. (2013). Perancangan Film Pendek Mengenai "Bully".

Dwipayanti \& Indrawati, K. R. (2014). Hubungan Antara Tindakan Bullying dengan Prestasi Belajar Anak Korban Bullying pada Tingkat Sekolah Dasar Ida Ayu Surya. Jurnal Psikologi Udayana, 1(2), 251-260.

Eisenberg, M. E. \& Aalsma, M. C. (2005).

Bullying and peer victimization: Position paper of the Society for Adolescent Medicine. Journal of Adolescent Health, 36(1), 88-91.

Fajrin, A. N. (2013). Hubungan Antara Tingkat Pengetahuan Dengan Perilaku Bullying Pada Remaja Di Smk Pgri Semarang. Universitas Muhammadiyah Semarang.

Firmansyah, T. (2014). Aduan Bullying Tertinggi.

Green, R., Collingwood, A. \& Ross, A. (2010). Characteristics of bullying victims in schools. Religion, 117. https://doi.org/892d

Harris, S. \& Petrie, G. F. (2003). Bullying: The Bullies, the Victims, the Bystanders. Texax: Scarecrow Press.

Lai, S.-L., Ye, R. \& Chang, K.-P. (2008). Bullying in middle schools: An AsianPacific Regional study. Asia Pacific Education Review, 9(4), 503-515. https://doi.org/10.1007/BF03025666

Leviani. (2008). Konformitas dan Bullying pada Siswa. Jurnal Psikologi, 6(1), 1.

Magfirah, U. \& Rachmawati, M. A. (2009). Fakultas Psikologi dan Ilmu Sosial Budaya Universitas Islam Indonesia.

Nation, M., Vieno, A., Perkins, D. D. \& Santinello, M. (2008). Bullying in school and adolescent sense of empowerment: an analysis of relationships with parents, friends, and teachers. Journal of Community \& Applied Social Psychology, 18(3), 211-232. https://doi.org/10.1002/casp.921

Notoatmodjo. (2010). Metodologi Penelitian Kesehatan. Jakarta: Rineka Cipta.

Nurhamzah, W., Maureen, A. \& Wiguna, T. (2013). Gambaran Bullying dan Hubungannya dengan Masalah Emosi dan Perilaku pada Anak Sekolah Dasar, 
15(3), 174-180.

Santoyosep. (2013). Bullying Di Sekolah , Cara Pencegahan Dan Penanganannya.

Sari, T. D. (2015). Aksi Bullying di Kalangan Siswa Sekolah Menengah Atas Wilayah Surakarta Tahun 2014/2015. Universitas Sebelas Maret.

Sejiwa, Y. S. (2008). Bullying: mengatasi kekerasan di sekolah dan lingkungan sekitar anak. Jakarta: Gratisindo.

Setyawan, D. (2014). KPAI : Kasus Bullying dan Pendidikan Karakter, Komisi Perlindungan Anak Indonesia (KPAI).

Soedjatmiko, S., Nurhamzah, W., Maureen, A. \& Wiguna, T. (2013). Gambaran Bullying dan Hubungannya dengan Masalah Emosi dan Perilaku pada Anak Sekolah Dasar. Sari Pediatri, 15(3), 174. https://doi.org/10.14238/sp15.3.2013.174 $-80$
Sugiariyanti. (2009). Perilaku Bullying Pada Anak dan Remaja. Jurnal Ilmiah Psikologi, 1, 101-108.

Usman, I. (2008). Perilaku Bullying Ditinjau Dari Peran Kelompok Teman Sebaya Dan Iklim Sekolah Pada Siswa Sma Di Kota Gorontalo. Fakultas Ilmu Pendidikan Universitas Negeri Gorontalo.

Usman, I. (2013). Kepribadian, komunikasi, kelompok teman sebaya, iklim sekolah dan perilaku. Jurnal Humanitas, 10(1), 50-60.

Wiyani, N. A. (2012). Save Our Children from School Bullying. Yogyakarta: Ar Ruzz Media.

World Health Organization (WHO). (2012). Health behavior in school aged children (HBSC) study:International report from the 2009-2010 survey. 